Original Research Paper

\title{
Use of the Nere Pod (Parkia Biglobosa) for the Improvement of Mechanical Properties of Soils
}

\author{
${ }^{1}$ Sinko Banakinao, ${ }^{2}$ Sonnou Tiem, ${ }^{2}$ Kodjo Attipou, ${ }^{2}$ Kossi Novinyo, \\ ${ }^{2}$ Komlan Lolo, ${ }^{3}$ Yao Koutsawa and ${ }^{4}$ Koffi-Sa Bedja \\ ${ }^{I}$ Department of Engineering Sciences, Laboratoire Génie-Civil ENSI, Université de Lomé, Togo \\ ${ }^{2}$ Laboratoire Génie-Mécanique ENSI, Université de Lomé, Togo \\ ${ }^{3}$ Department of Materials Research and Technology, \\ Luxembourg Institute of Science and Technology, 41, Rue du Brill, L-4422 Belvaux, Luxembourg, \\ ${ }^{4}$ Laboratoire Génie-Électrique ENSI, Université de Lomé, Togo
}

Article history

Received: 12-11-2015

Revised: 03-01-2017

Accepted: 14-02-2017

Corresponding Author:

Sinko Banakinao

Department of Engineering

Sciences, Laboratoire Génie-

Civil ENSI, Université de

Lomé, Togo

Email: topingenierie@ymail.com

\begin{abstract}
Buildings made of unbaked clay have some advantage in terms of production cost. However, they have some inconveniences concerning their mechanical performance, particularly their resistance to weather. The objective of this study is to minimize these disadvantages and to maximize the benefits of such buildings to make them more viable. For this purpose, a method based on a traditional practice where the néré pod is utilized as a color wash, as well as, a binder is used. In the first case (color wash), it is to protect the building against weather damage, in the latter case, it is used to improve the mechanical performance of the coatings on the ground and it is in this way that rural people use to keep more sustainable homes. To achieve this, geotechnical characteristics were studied on seven (07) soil samples collected in seven (07) localities in Togo (Kovié, Aouda Zanguéra, Sarakawa Tagbamba, Goumoukopé and BB Lomé). The same geotechnical characteristics were studied on the same soil samples enhanced by adding the néré pods. Finally, a study was conducted to optimize the performance of this new composite material (soil-néré pod) based on the proportion of néré pod within the material. To manufacture a brick of dimensions of $22 \times 14 \times 9.5 \mathrm{~cm}, 8.5 \mathrm{~kg}$ of the mixture was needed and the amount of dampening water needed was equal to the amount of water to obtain optimum Proctor plus $2 \%$. The results of these tests confirmed that néré pods help to improve the mechanical performance, especially the resistance to compression and puncture of the soils under consideration.
\end{abstract}

Keywords: Californian Bearing Ratio (CBR), Civaram, Néré, Parkia Biglobosa, Siliceous

\section{Introduction}

Earth is one of the most used materials in the world, even today. Despite the performance of binding materials such as cement, lime, bitumen and tar, questions concerning energy costs and the effects of harmful manufacturing techniques on the environment are raised for these materials (Alshaaer et al., 2010; Turanli et al., 2003). Therefore, land still holds the record for the most used material in construction. In Africa, almost all roads are made of granular materials (earth) and a number of traditional buildings and structures are earthen. It is estimated that $30 \%$ of the world's population is living in land-made buildings.
Furthermore, $17 \%$ of the works included as UNESCO World Heritage sites are earthen buildings (Alshaaer et al., 2010). In Togo and Benin, two neighboring countries in West Africa, $70 \%$ of residential buildings are earthen (Padenou and Barrue-Pastor, 2006). The percentage of earthen buildings is much higher in rural areas. Some of these buildings are considered a cultural expression, as in the case of Tata Temberma in the north of Togo, which is a UNESCO World Heritage site. The problem with these buildings made of earthen materials is their low strength and resistance to weather, making them less durable (Keita et al., 2014). This deficiency results in high maintenance costs or massive renovations. To overcome this 
problem, various local materials are used. In traditional African practices, straw, cow -dung, boiled skins and banana leaves are used along with earthen materials. In northern Togo and Benin, néré tannins are used to brush the outside walls and the courtyard of concessions (Sorgo et al., 2014). In Burkina Faso and Mali, néré tannins are also used to paint pottery or to dye cotton fabric crockery (Diallo et al., 1994; Blanchart et al., 2010). A review of previous studies shows that in traditional practices, various local materials are used to protect exterior siding of walls made of earthen against the weather and elements (Fontaine and Ange, 2009). Among the materials commonly used, néré tannins holds an important place. It is also noteworthy that tannins have become a subject of renewed attention in recent decades for use in several areas, such as environment friendly biosourced polymeric materials (Nouailhas et al., 2011; Celzard et al., 2012; Kuzhir et al., 2012; Abdullah et al., 2013; Amaral-Labat et al., 2013; Li et al., 2013; Thebault et al., 2014; Basso et al., 2014). Of all of the uses of tannins, our study is inspired by the traditional practice where locust bean pod tannins are used to improve the durability of traditional housing. The aim of our investigations is to find a local biohydrofuge product that can be used as a binder capable of improving the soil's mechanical properties to make the earth structures more resistant to loads and weather. Our study will analyze conditions where husks of néré are used in composite materials (earthnéré pod) to optimize the mechanical performance of the composite material. Subsequently, we will also show that the néré pod could be used to stabilize néré granular materials used in road construction to increase the lifetime of the road.

\section{Composite Materials}

\section{Tests of Characterization of Collected Soil Samples}

Tests performed to characterize the collected soil samples are performed to know the nature and the mechanical performance of non-stabilized soil and the composite materials. These tests are performed according to the following standards: granulometric analysis (NF P 94-056), the specific weigh (NF P 94054), Atterberg limits (NF P 94-051), Proctor (NF P 94093), CBR test (NF P 94-078)] and simple compression test (NF P18-411).

\section{Small Equipment used for Testing}

The small materials used for the test include tares, sieves of the series AFNOR, an electric sieve shaker, an electronic scale, a Casagrande cup, a tool to groove a smooth marble slab, an oven, a dryer, molds CBR, a modified Proctor lady, graduated cylinders, a CBR press, a Civaram press and a 3000 kN NF P18-411 press.

\section{Materials Used}

Seven (07) soil samples were taken from seven (07) locations in Togo (Table 1).

\section{Tannins Néré Pods}

The binder used is a powder that comes from the néré pod (Parkia biglobosa) (Sina and Traoré, 2002) to produce this powder, the néré pod underwent several operations. It had to be dried at $50^{\circ} \mathrm{C}$, then all foreign matter was removed from the pod by hand; furthermore, this step reduced the pod into smaller components; then, it was transitioned through the mill for grinding, the powder was then sieved through a $1 \mathrm{~mm}$ sieve (Fig. 1-4). It is the fine powder obtained through a $1 \mathrm{~mm}$ sieve that was then used as binder to be mixed with the various soil samples. The binder contained in this powder is hydrolysable néré tannins. Previous studies have revealed that the néré pod is a very interesting natural product because it has a high concentration of phenolic compounds containing hydrolysable tannins. These hydrolysable tannins are easily extracted by a simple and inexpensive method of decoction at low temperatures $\left(30-40^{\circ} \mathrm{C}\right)$ (Keita et al., 2014). After drying, the néré pod was mixed with water (40 g per liter of water); after three days of imbibition at room temperature, the filtered solution contained $9.6 \mathrm{~g}$ of dry material per liter and $6.3 \mathrm{~g}$ of tannins (Singleton et al., 1999). This amount of tannin in the néré pod is relatively high compared to that obtained with different trees in different regions of Africa (Makkar and Becker, 1998). Complementary analyses of decoction, performed by visible spectroscopy (Lambda spectrometer UV/Vis and quartz cell) proved the predominance of hydrolysable tannins, mainly gallic acid (Zerbo et al., 2014).

The use of tannins is a popular research area and Benin has shown that néré tannins gives good results in the stabilization of expansive soil. Tannins are also used in the manufacture of particle board in (Kadja et al., 2011). In this latter, water was used to moisten the mixture and form a mortar.

\section{Pull Optimization Tests}

During the lift optimization tests, néré pod powder was mixed with different soils (Table 1) to obtain a composite soil material. To determine the optimal lift for each of the soil samples, the rate of néré pod was varied at a scale of $1 \%$ and the various mixtures obtained were tested (CBR) after being soaked for 96 h. (Fig. 5).

\section{Brick Manufacturing has Improved with Néré Pods}

The mixtures were obtained by varying the néré pod at steps of $1 \%$ to make bricks. For each dose of néré pod, 72 bricks were manufactured using a Civaram press. To manufacture a brick with dimensions of $22 \times 14 \times 9.5 \mathrm{~cm}, 8.5$ $\mathrm{kg}$ of the mixture was needed and the amount of dampening water needed was equal to the amount of water needed to obtain the optimum Proctor plus 2\% (Fig. 6). 


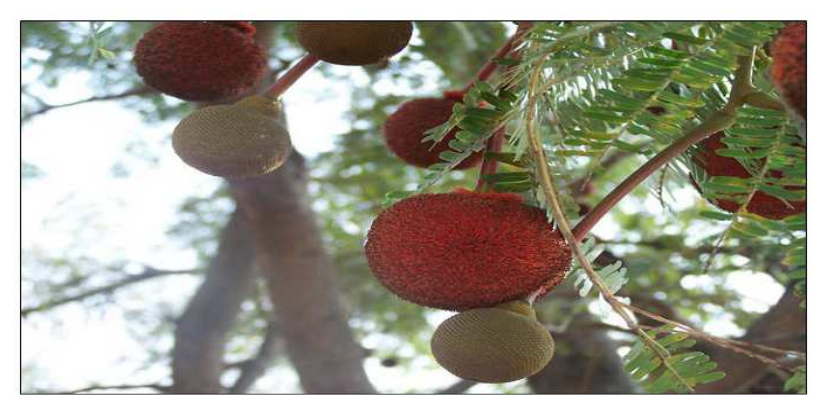

Fig. 1. Picture of a néré tree

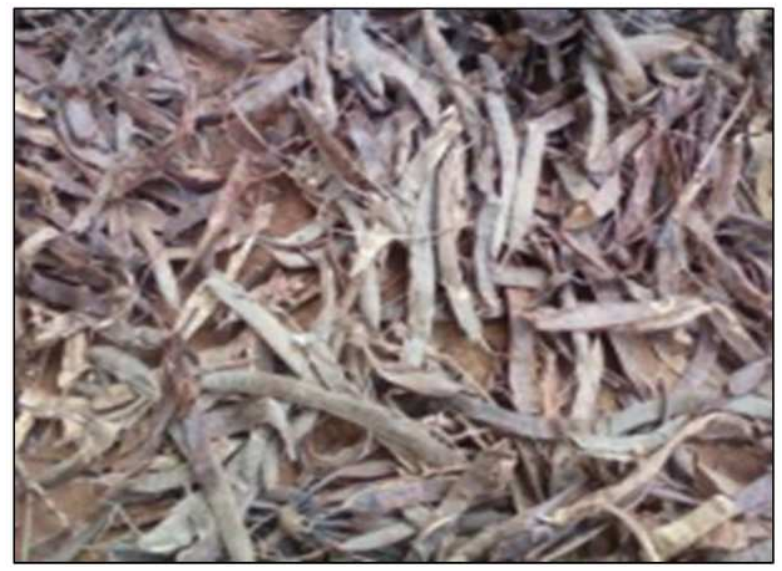

Fig. 2. Néré pod

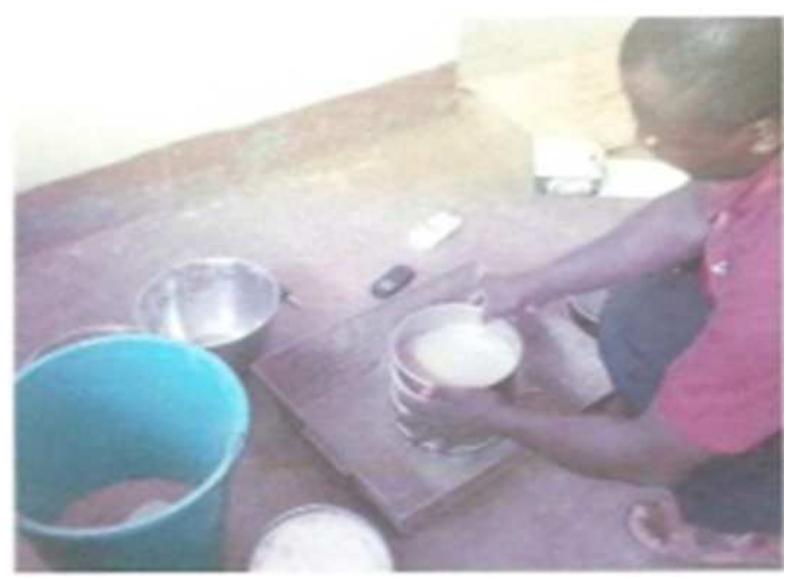

Fig. 3. Screening

Table 1. Specimen collection locations

Place of

\begin{tabular}{llll}
$\begin{array}{l}\text { Specimen } \\
\text { numbers }\end{array}$ & $\begin{array}{l}\text { specimen } \\
\text { collection }\end{array}$ & Prefectures & Regions \\
\hline 1 & Kovié djémékpé & Zio & Maritime Region \\
2 & Sarakawa & Kozah & Kara Region \\
3 & Tagbamba & Oti & Savannah Region \\
4 & Aouda & Sotouboua & Central Region \\
5 & Goumoukopé & Lacs & Maritime Region \\
6 & Zanguéra & Golf & Maritime Region \\
7 & BB Lomé & Golf & Maritime Region \\
\hline
\end{tabular}

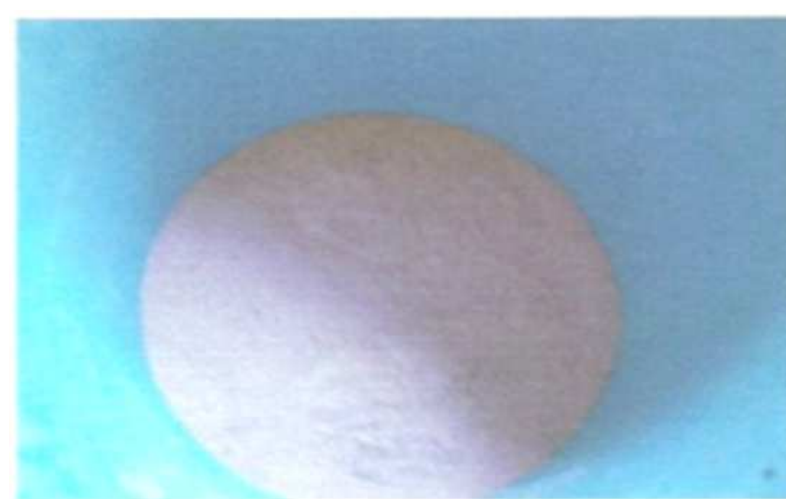

Fig. 4. Powder obtained
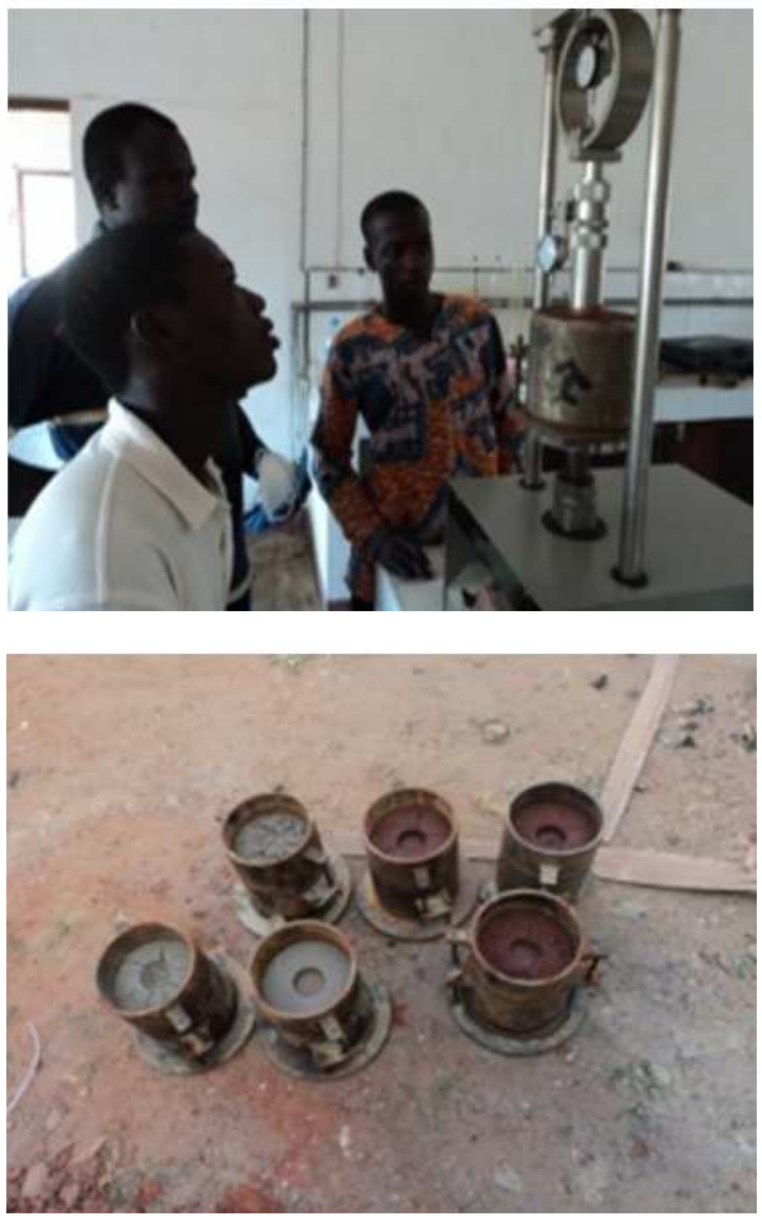

Fig. 5. Pictures of the punching trial

\section{Conservation and the Simple Compression Test of the Bricks}

The seventy-two (72) bricks that were made for each dose of néré pod were divided and kept in four different ways: 18 were exposed to the sun but not watered, 18 were exposed to the sun and watered, 18 were in the shade but not watered and 18 were in the shade and watered. 

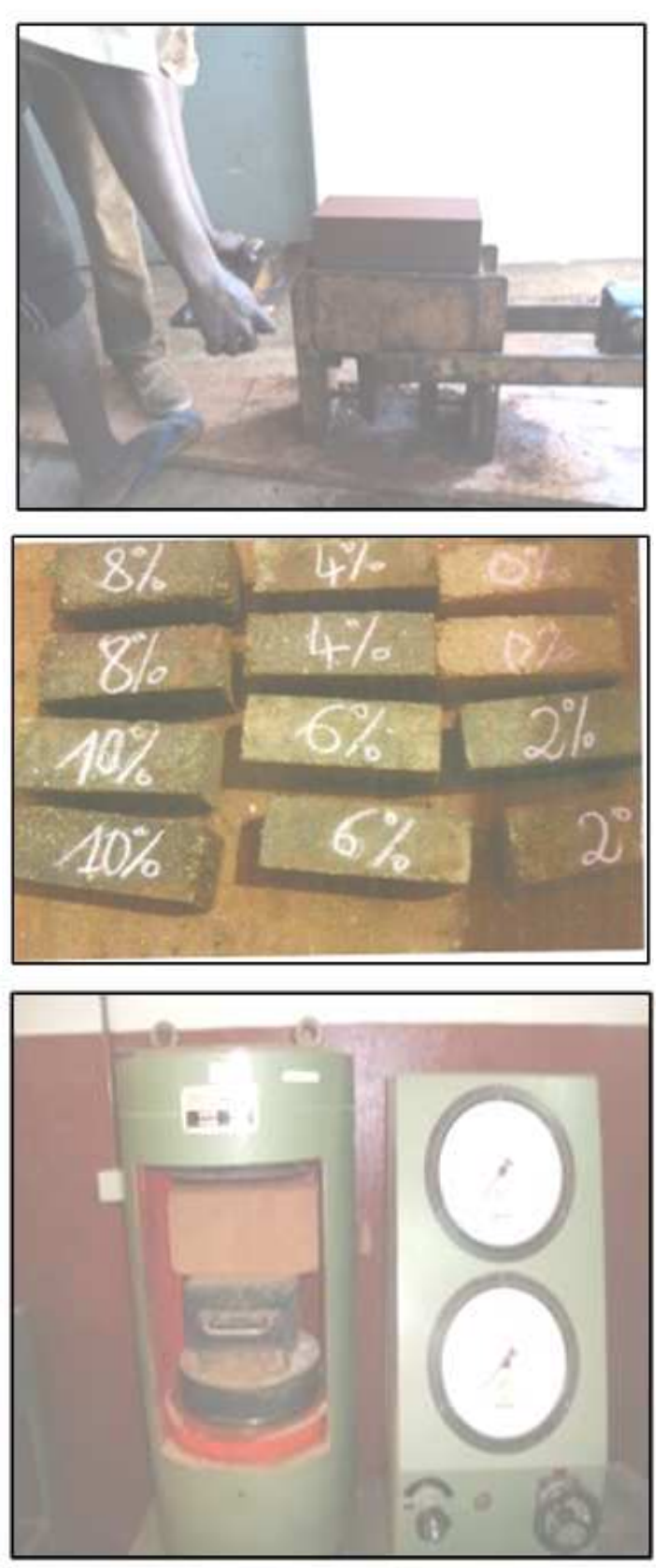

Fig. 6. Photos of manufacturing, conservation and brick crashing

Three bricks in each batch were crushed the 7th, 28th and 90 th day after manufacture. The press used was a 3000 kN NF P18-41 press (Fig. 6).

\section{Results and Discussion}

Characterization Tests Performed on Raw
Materials

The results obtained from tests on raw materials are shown in Table 2 and Fig. 7. These results represent the granulometric size distribution of the soils studied.

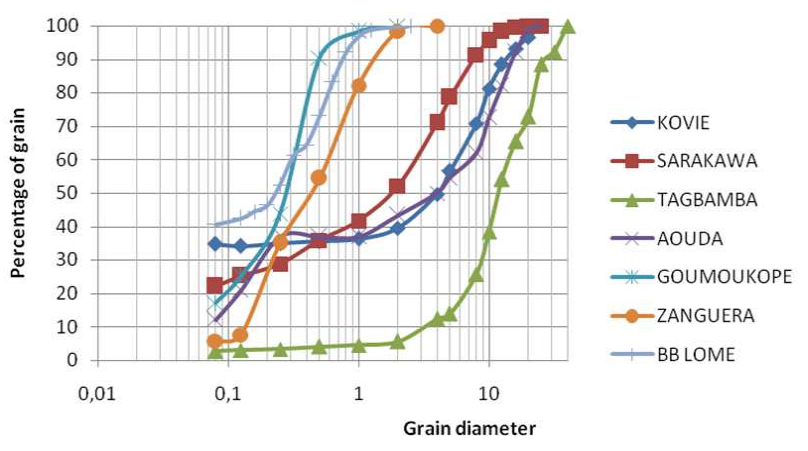

Fig. 7. Curve of granular soils distribution

From these results, four groups of soil were identified: Sarakawa soils (Norme NF P 94-054), Tagbamgba soils (Norme NF P 94-051) and Aouda soils (Norme NF P 94-093), which are lateritic with a fine silty matrix, Zanguera soils (Norme NF P 94-078), which are fine sands, Goumoukopé soils (Norme NF P 18-411) which are sand with a silty fine matrix and finally, BB Lomé soils, which are sand with a fine clay matrix.

\section{Proctor and CBR Tests}

Results from proctor and CBR tests performed on raw materials (without néré pods) and on improved earth (composites with optimal dose of néré pod) are presented in Table 3.

From these results, the following information can be drawn:

- The optimum dosage of néré pod varies depending on the nature of the soil; however, the gap variation remains within the range of $2 \%$

- The density of composites decreases relative to raw materials

- The CBR of raw materials varies depending on the nature of the soil; it varies from 7 to 10 for clayey sands and silty sands and for laterites, the minimum value is 40 while the maximum value is 52

- The CBR of the composite materials increases relative to the raw materials and the extent of increase depends on the nature of the soil

- For clayey and silty soils with a fine matrix, the CBR increase is significant; however, low values remain, ranging from 32 to 90 . For laterites, the increase is significant ranging from 84-130 (Fig. 8). These values are much higher than $\mathrm{CBR}$ values recommended for pavement layers at medium traffic levels (30 for the subbase and 80 for the base) (Makkar and Becker, 1998). This composite material earth-néré pod can therefore find its application in road construction (Banakinao, 2016) 


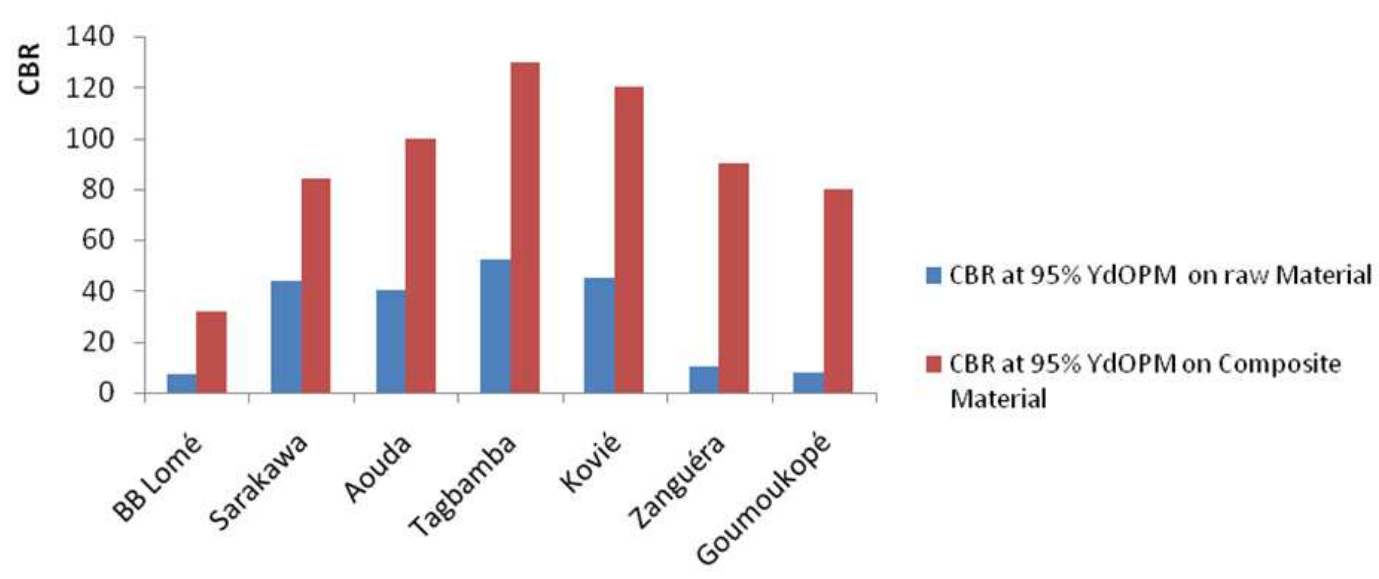

Place of specimen collection

Fig. 8. Variation of CBR in relation to the type of soil

Table 2. Result of the tests conducted on raw materials

\begin{tabular}{|c|c|c|c|c|c|c|c|c|c|c|c|c|c|}
\hline \multirow{3}{*}{$\begin{array}{l}\text { Place of } \\
\text { collection }\end{array}$} & \multicolumn{4}{|c|}{ Granulometry } & \multirow{2}{*}{\multicolumn{5}{|c|}{ Limits Of atterberg }} & \multirow{2}{*}{\multicolumn{3}{|c|}{ Classification }} & \multirow{3}{*}{$\begin{array}{r}\text { Full idendity } \\
\text { Lieu de prélèvement }\end{array}$} \\
\hline & \multirow[b]{2}{*}{$\gamma \mathrm{S}_{(\mathrm{g} / \mathrm{cm})}$} & \multirow{2}{*}{$\begin{array}{l}\text { Dmax } \\
(\mathrm{mm})\end{array}$} & \multirow{2}{*}{$\begin{array}{l}<0,08 \mathrm{~mm} \\
(\%)\end{array}$} & \multirow{2}{*}{$\begin{array}{l}<2 \mathrm{~mm} \\
(\%)\end{array}$} & & & & & & & & & \\
\hline & & & & & VBS & LL (\%) & LP (\%) & IP $(\%)$ & IC & $\mathrm{LCPC}$ & HBR & GTR & \\
\hline Kovié & 2.68 & 20.00 & 33.77 & 39.5 & 2.7 & 415 & 27.37 & 14,13 & 2.96 & SL & A2-7 & B6 & Silty Lateritic Sand \\
\hline Sarakawa & 2.69 & 10.00 & 22.25 & 52.1 & 0.8 & 33,5 & 21.54 & 11,96 & 2.1 & SL & A2-6 & B5 & Silty Lateritic Sand \\
\hline Tagbamba & 2.67 & 36.00 & 2.78 & 5.56 & 0.3 & 29 & 22.5 & 6,5 & 2.19 & SB & A2-4 & B3 & Bold Laterite \\
\hline Aouda & 2.68 & 22.00 & 12.03 & 43.4 & 1.6 & NP & NP & NP & NP & SL & A3 & B4 & Silty Lateritic Sand \\
\hline Goumoukopé & 2.68 & 1.00 & 17.16 & 100 & 4.3 & NP & NP & NP & NP & SL & A3 & B6 & Silty Sand \\
\hline Kovié & 2.68 & 20.00 & 33.77 & 39.5 & 2.7 & 415 & 27.37 & 14,13 & 2.96 & SL & A2-7 & B6 & Silty Lateritic Sand \\
\hline Sarakawa & 2.69 & 10.00 & 22.25 & 52.1 & 0.8 & 33,5 & 21.54 & 11,96 & 2.1 & SL & A2-6 & B5 & Silty Lateritic Sand \\
\hline
\end{tabular}

Table 3. Proctor and CBR tests

\begin{tabular}{|c|c|c|c|c|c|c|c|c|}
\hline \multirow{2}{*}{$\begin{array}{l}\text { Nature of test } \\
\text { Place of } \\
\text { Collection }\end{array}$} & \multicolumn{4}{|c|}{ Proctor and $\mathrm{CBR}$ on raw material } & \multicolumn{4}{|c|}{ Proctor and CBR on Composite Material } \\
\hline & $\begin{array}{l}\text { Balance of } \\
\text { néré pod }(\%)\end{array}$ & $\mathrm{W}_{\mathrm{OPM}(\%)}$ & $\gamma \mathrm{d}_{\mathrm{OPM}}(\mathrm{g} / \mathrm{cm} 3)$ & $\begin{array}{l}\text { CBR at } \\
95 \%\end{array}$ & $\begin{array}{l}\text { Balance of } \\
\text { néré pod }(\%)\end{array}$ & $\mathrm{W}_{\mathrm{OPM}(\%)}$ & $\gamma \mathrm{d}_{\mathrm{OPM}}(\mathrm{g} / \mathrm{cm} 3)$ & $\begin{array}{l}\text { CBR at } 95 \% \\
\gamma \mathrm{d}_{\mathrm{OPM}}\end{array}$ \\
\hline Kovié & 0 & 15,1 & 2,2 & 45 & 9 & 16,25 & 1,91 & 120 \\
\hline Sarakawa & 0 & 11,36 & 2,14 & 44 & 10 & 13,10 & 1,79 & 84 \\
\hline Tagbamba & 0 & 9,65 & 2,30 & 52 & 9 & 11,10 & 2,01 & 130 \\
\hline Aouda & 0 & 9,60 & 2,18 & 40 & 10 & 11,05 & 1,80 & 100 \\
\hline Goumoukopé & 0 & 10,30 & 1,85 & 8 & 11 & 14,50 & 1,78 & 80 \\
\hline Zanguéra & 0 & 5,49 & 1,86 & 10 & 8 & 8,20 & 1,98 & 90 \\
\hline BB Lomé & 0 & 10,69 & 2,05 & 7 & 10 & 13,90 & 1,80 & 32 \\
\hline
\end{tabular}

Table 4. Simple compression tests

\begin{tabular}{|c|c|c|c|c|c|c|c|c|}
\hline $\begin{array}{l}\text { Place of } \\
\text { Collection }\end{array}$ & $\begin{array}{l}\text { Balance } \\
\text { of néré } \\
\text { Pod }(\%)\end{array}$ & $\begin{array}{l}\text { Résistance to } \\
\text { compression on } \\
\text { the } 7^{\text {th }} \text { day (Bars) }\end{array}$ & $\begin{array}{l}\text { Résistance to } \\
\text { compression on } \\
\text { the } 28^{\text {th }} \text { day }\end{array}$ & $\begin{array}{l}\text { Résistance to } \\
\text { compression on } \\
\text { the } 90^{\text {th }} \text { day }\end{array}$ & $\begin{array}{l}\text { Balance } \\
\text { of néré } \\
\text { Pod }(\%)\end{array}$ & $\begin{array}{l}\text { Résistance to } \\
\text { compression on } \\
\text { the } 7^{\text {th }} \text { day (Bars) }\end{array}$ & $\begin{array}{l}\text { Résistance to } \\
\text { compression on } \\
\text { the } 28^{\text {th }} \text { day }\end{array}$ & $\begin{array}{l}\text { Résistance to } \\
\text { compression on } \\
\text { the } 90^{\text {th }} \text { day }\end{array}$ \\
\hline Kovié & 0 & 9.81 & 10.32 & 10.35 & 9 & 15.24 & 27.24 & 30.06 \\
\hline Sarakawa & 0 & 5.16 & 8.61 & 8.64 & 10 & 17.22 & 2.0 .2 & 32.00 \\
\hline Tagbamba & 0 & 8.24 & 12.82 & 12.82 & 9 & 20.15 & 32.35 & 30.15 \\
\hline Aouda & 0 & 6.24 & 7.61 & 7.65 & 10 & 18.21 & 35.25 & 39.10 \\
\hline Goumoukopé & 0 & 0.00 & 0.00 & 0.00 & 11 & 9.83 & 13.52 & 27.00 \\
\hline Zanguéra & 0 & 0.00 & 0.00 & 0.00 & 8 & 18.15 & 22.00 & 32.00 \\
\hline BB Lomé & 0 & 6.87 & 5.25 & 5.30 & 10 & 23.77 & 16.87 & 28.27 \\
\hline
\end{tabular}

\section{Simple Brick Compression Tests}

The results of the simple compression test for the bricks on the 7th, 28th and 90th day after manufacture are summarized in Table 4.
These results show the following:

- It is impossible to make bricks from soil of Zanguéra or Goumoukopé that have a fine silty matrix, when these soils are without néré pods or when they are 
improved with $5 \%$ néré pods. The fabrication of bricks is not possible when the amount of néré pods is not increased to reach $6 \%$. Optimal resistors of 32 and 27 bars are obtained, respectively, for Zanguéra and Goumoukopé soils 90 days after manufacture with $8 \%$ and $10 \%$ pods of néré, respectively

- Lateritic soils with silty matrix gave the best resistance to compression after 90 days, with 30.06 bars for Kovié, 32.00 bars for Sarakawa, 30.15 bars for Tagbamba and 39.10 bars Aouda

- The compressive strength of the bricks made of fine clayey sands of plastic matrix and of néré pod from BB Lomé has not shown much variation between the 28th day (5.25 bar) and the 90th day (5.30 bar); however, the resistance to compression continues to grow significantly from the 28th day, when the conservation of the bricks is made in the sun. When the soil contains $10 \%$ of the néré pod, the compressive strength reaches a maximum value of 28.27 bars after 90 days

- When the bricks are wet, the compressive strength is much lower regardless of the type of soil and the age of the bricks; however, if the bricks are dried, they become very solid and can reach a maximum value after 90 days. These results confirm an earlier study on composite materials made of clay and tannin néré, where the values obtained were ranging between 27.2 and 33.2 bars (Banakinao et al., 2016; Keita et al., 2014). This high compressive stress may find its application in construction where the results in (Banakinao, 2016) advise minimum stresses of 25 bars for buildings of Ground floor type: +1 .

\section{Conclusion}

- The optimization of the néré pod determined by a maximum dosage of $10 \%$ should be used for Kovié, Auda, Sarakawa and BB (Brasserie of Benin) of Lomé soils, $9 \%$ for Tagbamgba soil, $8 \%$ for Zanguera soil and $12 \%$ for Goumoukopé soil

- The results obtained from the characterization of the improved earth (earth composite material with the maximum percentage of néré pod) provide a compressive resistance for bricks of dimension $22 \times 14 \times 9 \mathrm{~cm}$ of 30.06 bars for Kovié soil, 32.00 bars for Sarakawa soil, 30.15 bars for Tagbamgba soil, 39.10 bars for Auda soil, 28.27 bars for BB of Lomé soil, 32.00 bars for zanguera soil and 27.00 bars for Goumoukopé soil

- The California Bearing Ratio (CBR) at 95\% of the optimum Proctor was 120 for the Kovié soil, 84 for Sarakawa soil, 130 for Tagbamgba soil, 100 for Aouda soil, 90 for Zanguera soil, 80 for Goumoukopé soil and 32 for BB of Lomé soil
- The values of pull (CBR) at $95 \%$ of the optimum Proctor for lateritic soils range from 84 to 130 . Therefore, this composite material earth-néré pod can find its application in road construction

- This composite material can easily find its application in building and road construction; it is a material to promote to resolve housing problems, as well as, develop the economies in poor countries by strengthening the road network

\section{Acknowledgement}

The authors sincerely thank Laboratoire du Centre Régional de Formation pour Entretien Routier (CERFER), Laboratoire National des Travaux Publics (LNBTP), Laboratoire de mécanique des sols de l'Ecole Nationale Supérieure des Ingénieurs de l'Université de Lomé(ENSI-UL) and the Laboratoire d'Etude et de Recherche sur le Matériau Bois (LERMAB) in France fort heir support. We also acknowledge our colleagues from various departments of génie-civil, génie-électrique and génie-mécanique from Ecole Nationale Supérieure des Ingénieurs de l'Université de Lomé (ENSI-UL) for their assistance.. May all of the readers during the publishing process find here our thanks for their helpful comments and corrections.

\section{Author's Contributions}

Sinko Banakinao: Participated in the designed the research plan, realized all experiments and coordinated the data-analysis and the writing of the manuscript.

Sonnou Tiem: Designed the research plan, organized the study and participated in the interpretation of the results.

Kodjo Attipou: Participated in the writing of the manuscript in French and its translation in English.

Kossi Novinyo: Contributed to the writing of the manuscript and the interpretation of the results.

Komlan Lolo: Participated in all experiments.

Yao Koutsawa: Gives final approval of the version to be submitted and all revised version.

Koffi-Sa Bedja: Contributed in reviewing the article in it critically for significant intellectual content.

\section{Ethics}

This article is original and contains unpublished material. The corresponding author confirms that all of the other authors have read and approved the manuscript and no ethical issues involved.

\section{References}

Abdullah, U.H., A. Pizzi, X. Zhou, K. Rode and L. Delmotte et al., 2013. Mimosa tannin resins for impregnated paper overlays. Eur. J. Wood Prod., 71: 153-153. DOI: 10.1007/s00107-012-0652-5 
Alshaaer, M., F. Slaty, H. Khoury, H. Rahier and J. Wastiels, 2010. Development of low-cost functional geopolymeric materials. Ceram Trans., 222: 159-167. DOI: 10.1002/9780470930991.ch15

Amaral-Labat, G., C. Zollfrank, A. Ortona, S. Pusterla and A. Pizzi et al., 2013. Structure and oxidation resistance of micro-cellular $\mathrm{Si}-\mathrm{SiC}$ foams derived from natural resins. Ceram. Int., 39: 1841-1851. DOI: 10.1016/j.ceramint.2012.08.032

Banakinao, S., S. Tiem, K. Lolo, Y. Koutsawa and K.S. Bedja, 2016. Dataset of the use of tannin of néré (parkia-biglobosa) as a solution for the sustainability of the soil constructions in West Africa. Data Brief, 8: 474-483. DOI: $10.1016 /$ j.dib.2016.05.072

Banakinao, S., 2016. Characterization and modeling of the mechanical behavior of heterogeneous microstructures: Case of the composite material soilpod of néré and its applications in civil constructions. PhD Thesis, University of Lomé.

Basso, M.C., S. Giovando, A. Pizzi, H. Pasch and N. Pretorius et al., 2014. Flexible-elastic copolymerized polyurethane-tannin foams. J. Applied. Polym. Sci. DOI: 10.1002/app.40539

Blanchart, P., A. Dembele, C. Dembele, M. Plea and L. Bergstrom et al., 2010. Mechanism of traditional Bogolan dyeing technique with clay on cotton fabric. Applied Clay Sci., 50: 455-460. DOI: 10.1016/j.clay.2010.08.029

Celzard, A., G. Tondi, D. Lacroix, G. Jeandel and B. Monod et al., 2012. Radiative properties of tannin-based, glasslike, carbon foams. Carbon, 50: 4102-4113.

DOI: 10.1016/j.carbon.2012.04.058

Diallo, B., M. Vanhaelen and O. Gosselain, 1994. Plant constitutents involved in coating practices among traditional African potters. Cell Mol. Life Sci., 51: 95-97. DOI: 10.1007/BF01964928

Fontaine, L. and R. Ange, 2009. Building on Land: The Gain of Sand to Architecture. 1st Edn., The City of Sciences and Industry, pp: 224.

Kadja, K., M. Banna, K.E. Atcholi and K. Sanda, 2011. Utilization of bone Adhesive to produce particleboards from stems of cotton plant at the pressing temperature of $140^{\circ} \mathrm{C}$. Am. J. Applied Sci.. 8: 318-322. DOI: 10.3844/ajassp.2011.318.322

Keita, I., B. Sorgho, C. Dembele, M. Plea and I. Zerbo et al., 2014. Ageing of clay and clay-tannin geomaterials for building. Construct. Buil. Mater., 61: 114-119.

DOI: 10.1016/j.conbuildmat.2014.03.005

Kuzhir, P.P., A.G. Paddubskaya, M. Shuba, S. Maksimenko and A. Celzard et al., 2012. Electromagnetic shielding efficiency in Ka-band: Carbon foam versus epoxy/carbon nanotube composites. J. Nanophoton., 6: 061715.

DOI: $10.1117 / 1 . J N P .6 .061715$
Li, X., A. Nicollin, A. Pizzi, X. Zhou and A. Sauget et al., 2013. Natural tannin-furanic thermosetting moulding plastics. RSC Adv., 3: 17732-17740. DOI: $10.1039 / C 3 R A 43095 B$

Makkar, H.P.S. and K. Becker, 1998. Do tannins in leaves of trees and shrubs from African and Himalayan regions differ in level and activity? Agrofor. Syst., 40: 59-68. DOI: $10.1023 / \mathrm{A}: 1006027231497$

Nouailhas, H., C. Aouf, C. Le Guerneve, S. Caillol and B. Boutevin et al., 2011. Synthesis and properties of biobased epoxy resins. part 1. Glycidylation of flavonoids by epichlorohydrin. J. Polym. Sci., Part A, Polym. Chem., 49: 2261-2270. DOI: $10.1002 /$ pola. 24659

Padenou, G.H. and M. Pastor-Barrué, 2006. Architecture, Société et Paysage Bétammaribé au Togo: Contribution à L'anthropologie de L'habitat. Presses Univ. du Mirail, Toulouse, ISBN-10: 2858168725, pp: 319.

Singleton, V.L., R. Orthofer and R.M. Lamuela-Raventós, 1999. Analysis of total phenols and other oxidation substrates and antioxidants by means of FolinCiocalteu reagent. Meth. Enzymol., 299: 152-178. DOI: 10.1016/S0076-6879(99)99017-1

Sorgo, B., I. Zerbo, I. Kéita, C. Dembele and M. Plea et al., 2014. Strength and creep behavior of geomaterials for building with tannin addition. Mater. Struct., 47: 937-946. DOI: $10.1617 / \mathrm{s} 11527-013-0104-7$

Thebault, M., A. Pizzi, S. Dumarcey, P. Gerardin and E. Fredon et al., 2014. Polyurethanes from hydrolysable tannins obtained without using isocyanates. Ind. Crops Prod., 59: 329-336.

DOI: 10.1016/j.indcrop.2014.05.036

Turanli, L., F. Bektas and P.J.M. Monteiro, 2003. Use of ground clay brick as a pozzolanic material to reduce the alkali-silica reaction. Cem. Concr. Res., 33: 1539-1542. DOI: 10.1016/S0008-8846(03)00101-7

Zerbo, O., C. Yoshida, J.K. Grether, J.V. de Water and P. Ashwood et al., 2014. Neonatal cytokines and chemokines and risk of Autism Spectrum Disorder: The Early Markers for Autism (EMA) study: A case-control study. J. Neuroinflammat., 11: 113-113. PMID: 24951035

Sina, S. and S.A. Traoré, 2002. Parkia biglobosa (Jacq.) R.Br. ex G.Don. Record from protabase. In: Plant Resources of Tropical Africa/Ressources Végétales de l'Afrique Tropicale, Oyen, L.P.A. and R.H.M.J. Lemmens, (Eds.), Wageningen, The Netherlands. 